W e live in complex, challenging times. In March 2020 a novel coronavirus called COVID-19 transformed our lives. Then, several months into shelterin-place orders for the virus, George Floyd was killed in police custody. For weeks we saw Black Lives Matter protests around the world demanding change. Floyd's death inspired new, open discussions about oppression, systemic racism, and the current and historical injustices faced by Black, Indigenous, and People of Color (BIPOC).

For many of us this moment represents an incredible turn of events-an opening of hearts, minds, and beliefs on a global scale. In only three months we've seen awakenings and calls for change with the potential of more lasting and sustainable change to policing than we have witnessed in a generation. Will this emerging consciousness also lead us to change what we believe about civil rights for all, the prison industrial complex, food insecurity, global climate change, and wealth inequality?

The energy and focus that have shed light on racism, oppression, and inequality seem to have disrupted the kinds of change we once believed was possible in our society. Couldn't this energy and newfound consciousness extend to our profession as well? How can we-individual college and research librarians, archivists, and leaders, as well as those working for our information, knowledge, publishing, and scholarship vendors and companies-shed light on the seen and unseen mountains we face? Doesn't our profession also have a clear obligation to navigate individual and organizational awakenings around race, class, and privilege, as well as the way we serve our institutions? If so, can we actively commit to working on a generational change that positions our profession well into the future?

This may be the opportune moment to focus on creating a more welcoming profession by becoming leaders in equity, diversity, and inclusion on our campuses. By the same token, this could be an opportunity to propose different approaches to the process, product, and price of scholarly communication. It could also be the right time to think long-term about scholarly communication overall and the daunting fiscal realities at our local institutions. Our institutions, our local and state municipalities, and our businesses large and small are like a family experiencing the effects of a global pandemic: we are all

Jon E. Cawthorne is dean at Wayne State University Library System, including the School of Information Sciences, email: jon.cawthorne@wayne.edu

() 2020 Jon E. Cawthorne 
trying to figure out our next steps. Could we also work on something equally big in our profession? I see incredibly steep mountains ahead but not impassible ones. At this unprecedented moment, if we focus only on what is in front of our noses, or try to return to what once was, we may miss the real opportunity that is presenting itself to rethink, redesign, and reimagine scholarly communication that not only leads the academy but also changes the world.

\section{A call to action}

Toward this purpose, I propose a threestep, positive call to action for individuals, for leaders of our organizations, and for creating new ways of working together. This call to action requires a deep, systemic change in thinking coupled with flexibility on the part of each one of us as we craft solutions; it asks more of current and future leaders within organizations across our college and research libraries; and it demands a new way to dialogue across our information industry to address the longterm sustainability of scholarly communication.

First and foremost, this call to action focuses on each of us as individuals. If you are not a BIPOC, consider this a time to listen, be curious, remain humble, and stay open to learning unfamiliar ways of knowing. In Ibram X. Kendi's award-winning book, How to be Anti-racist ${ }^{1}$ the author argues that the foundations of racism do not emerge from ignorance and hate alone but also from self-interest-the kind of selfinterest that is so profoundly ingrained in economic, political, and cultural life that it may be hard for many of us to recognize or acknowledge it. All of us must do the necessary work, however, to unlearn our own deeply held beliefs and assumptions and to examine the actions that support all systems of oppression. In this moment, we have the opportunity, and indeed the obligation, to educate ourselves-to become more aware of our own self-interest and how that plays out in our families, our communities, our place of work. Black Lives Matter is just the beginning of that understanding. This moment also requires individuals to lean into discomfort, allowing vulnerability and empathy to be part of the process, as they work toward racial justice. And, yes, this is hard work.

The second call is for leadership to be present to the experience of people at all levels of college and research library organizations. Before the COVID-19 pandemic, our lives were so busy and hectic that we barely had time to relax or spend quality time with our families, let alone think about ways to make the world a better place. Now, months into the pandemic without a horizon in sight, we've learned how to work remotely and find new ways to connect with friends and family via technology.

Although we see no signs that the crisis will soon end, the coronavirus and social distancing have the potential to forever alter the ways we work, learn, and live. Leaders may now ask, How has the pandemic changed what we believe about the organizational culture we always thought was slow to change? If a culture is made up of what we believe, what do we now believe is possible in our organizations?

Third, as we consider individual and institutional actions in our rapidly changing environment, we must employ a new framework to more effectively dialogue both among ourselves and with outside vendors. Even before the pandemic, exciting conversations and thinking around open scholarship; ${ }^{2}$ new publishing ventures; ${ }^{3}$ and individual leaders, systems, and changes in the landscape of scholarly communication were all underway. ${ }^{4}$ Even more recently, transformational open access agreements have been announced. ${ }^{5}$ 
Ultimately, the outcome of this call to action must benefit all college and research libraries across higher education, which means focusing on the hundreds of millions of dollars we spend currently for scholarship. As we move into the next five to ten years, there may be fewer higher education institutions. How will changes in the current environment be affecting scholarship then? ${ }^{6}$ Just as we witness stark economic disparities in our society, our ability to keep paying for access to scholarly articles will certainly affect the library, the institution, and future scholarship, making current practices even more unsustainable. Borrowing from the field of law, the following example illustrates how this dialogue might occur.

Around 2015 I watched a documentary, The Decade of Discovery, by Joe Looby. On the surface this film is about electronic access to e-mail in a wrongful termination lawsuit. In the practice of law, the process of "discovery" happens when the prosecutor provides the entire case, including all evidentiary findings, to the defense attorney. The sharing that takes place between the prosecution and defense by means of discovery is understood to be essential to a just verdict. Unfortunately, over the years (and no one has pinpointed exactly when this happened), prosecutors had become disconnected from their role in discovery, and as a result the process became quite contentious, time-consuming, and expensive.

From the values taught in law school, there was a clear understanding that the practice of discovery had changed (albeit for the worse) and that this change had become part of the culture of practicing law. No one believed that the currently existing discovery process could budge, even though everyone (judges, prosecutors, and defense attorneys) could see that discovery, as it was then being practiced, was not resulting in equal justice, yet they could not see their way through to making systematic, sustain- able changes to what was then occurring in their profession.

What happened next has implications for a way forward for current practice in scholarly communication related to journal access and pricing. In order to address the culture of discovery, Richard G. Brahman established the Sedona Conference. This conference, which took place in Sedona, Arizona, brought together judges, prosecutors, and defense attorneys to dialogue, not debate, a solution to the issue of discovery. Brahman realized that lawyers are trained to debate, but using the principals in The Magic of Dialogue: Transforming Conflict into Cooperation by Daniel Yankelovich, ${ }^{7}$ he created a seminar-style dialogue. This resulted in 14 principles for transforming the culture of discovery. When these principles were presented at a professional law conference, the audience openly laughed at the notion of changing what had become so firmly established. While I imagine that this reaction was quite embarrassing, Brahman and the other committed individuals were determined to change the culture of discovery. Yes, it was hard work, but eventually the culture changed for the benefit of justice.

I see similarities in our professions for a much-needed cultural change. I appreciate Brahman's dialogue-centered leadership process, and I recognize his focused resolve to change the judicial culture around the issue of discovery. I find instructive and valuable the fact that not everyone at the Sedona Conference believed a big, sweeping, impactful change could even be accomplished. In fact, the conference leaders were initially laughed at by their peers. Can you imagine how halting that would be in our field?

\section{Conclusion}

In our library profession we have been collectively isolated from one another and have accepted silence and fear for far too long. This unprecedented inflec- 
tion point-starting with a deadly virus that has changed our lives in countless ways, followed by protests in the streets, where a new generation has been calling out for racial justice-is essentially about courage, the courage to change what no longer works. I believe we can and should take heart from this unprecedented moment and begin to stand up to the powerful forces in our own profession-to question, to argue, to disagree, and to plan a better way forward for all college and research libraries. For years we have experienced institutional change as a slow process, yet when we look at the societal changes that have taken place in the larger society over the last several months, we can see that culture only changes when people are willing to alter their own beliefs and actions.

College and research libraries have some steep mountains to climb as they seek to transform collection spending. In the face of such mountains, who among us is willing to work toward a new culture? Here is the hard truth that faces us: Outside of personnel budgets, library collections stand at the top of our spending. This is the case across all college and research libraries, as a result of our long-standing practice of buying back scholarship from vendors. Constructing and implementing a framework to address this systemic cultural issue will not be easy, I assure you. In fact, we know these mountains well-they appear in economics, in promotion and tenure, and in what we believe is possible. I know, however, that we can and will reach the other side and be ready to conquer new challenges, if we are willing to do the work that matters for all of us.

Collectively as well as individually, we are smart, capable, and care deeply about the work we do. Let's not look for or wait for perfection. Let's not set the bar too low. We can start by acknowledging that we will make mistakes, but that is how people learn. We are experiencing more change than we've seen in a generation. We have already adapted, and we know how to change. I believe that this moment of global transformation has arrived as a message to pay attention to the world we must now create. For academic librarians, archivists, salespeople, leaders, vendors, and all partners that help us bring services to our respective college and research institutions in 2020 and beyond, my great hope is that, together, we never let fear stop us from trying to improve our profession, our culture, and our future. And, yes, it will be hard work. So, let's begin.

\section{Notes}

1. Ibram X. Kendi, How to be an antiracist (One World, 2019).

2. Open Scholarship, http://osiglobal.org.

3. UC Santa Barbara Library, "UCSB Library Helps Lead \$3.6 Million Project to Improve Open Access Publishing Infrastructure," https://www. library.ucsb.edu/news/ucsb-library-helps -lead-36-million-project-improve-open-access -publishing-infrastructure.

4. SPARC, "Big Deal Cancellation Tracking: Open Access," https://sparcopen.org/our-work /big-deal-cancellation-tracking/.

5. Springer Nature Group, "Landmark Transformative Agreement Reached between Springer Nature and University of California," press release, London/New York, June 16, 2020, https:// group.springernature.com/gp/group/media /press-releases/springer-nature-university-of -california/18083344?utm_medium =social\&utm_content=organic\&utm_source $=$ twitter\&utm_campaign $=$ SpringerNature _\&sf234720256=1.

6. Gregory Barber, "Universities Step Up the Fight for Open-Access Research," Wired, accessed June 16, 2020, https://www.wired.com /story/universities-step-up-the-fight-for -open-access-research/.

7. Daniel Yankelovich, The Magic of Dialogue: Transforming Conflict into Cooperation (Touchstone, 2001). 